\title{
SOURCES AND SINKS OF CARBON DIOXIDE
}

\section{Tom Quirk}

twquirk@labyrinth.net.au

\begin{abstract}
The conventional representation of the impact on the atmosphere of the use of fossil fuels is to state that the annual increases in concentration of $\mathrm{CO}_{2}$ come from fossil fuels and the balance of some $50 \%$ of fossil fuel $\mathrm{CO}_{2}$ is absorbed in the oceans or on land by physical and chemical processes.

An examination of the data from:

i) measurements of the fractionation of $\mathrm{CO}_{2}$ by way of Carbon-12 and Carbon-13 isotopes,

ii) the seasonal variations of the concentration of $\mathrm{CO}_{2}$ in the Northern Hemisphere and iii) the time delay between Northern and Southern Hemisphere variations in $\mathrm{CO}_{2}$,

raises questions about the conventional explanation of the source of increased atmospheric $\mathrm{CO}_{2}$.
\end{abstract}

The results suggest that El Nino and the Southern Oscillation events produce major changes in the carbon isotope ratio in the atmosphere. This does not favour the continuous increase of $\mathrm{CO}_{2}$ from the use of fossil fuels as the source of isotope ratio changes. The constancy of seasonal variations in $\mathrm{CO}_{2}$ and the lack of time delays between the hemispheres suggest that fossil fuel derived $\mathrm{CO}_{2}$ is almost totally absorbed locally in the year it is emitted. This implies that natural variability of the climate is the prime cause of increasing $\mathrm{CO}_{2}$, not the emissions of $\mathrm{CO}_{2}$ from the use of fossil fuels. 


\section{INTRODUCTION}

The conventional representation of the impact on the atmosphere of the use of fossil fuels is to state that the annual increases in concentration of atmospheric $\mathrm{CO}_{2}$ come from fossil fuel emissions and the balance of some $50 \%$ of emissions is absorbed in the oceans or on land by chemical or biogenic interactions ${ }^{1}$. The annual changes at Mauna Loa ${ }^{2}$ are shown in Figures $1 \mathrm{~A}$ and $1 \mathrm{~B}$ along with the estimated production of $\mathrm{CO}_{2}$ from fossil fuels ${ }^{3}$. Note that the absorption shown in Figure 1B is simply found by subtraction of the atmospheric increase from the calculated emissions of $\mathrm{CO}_{2}$ shown in Figure 1A.

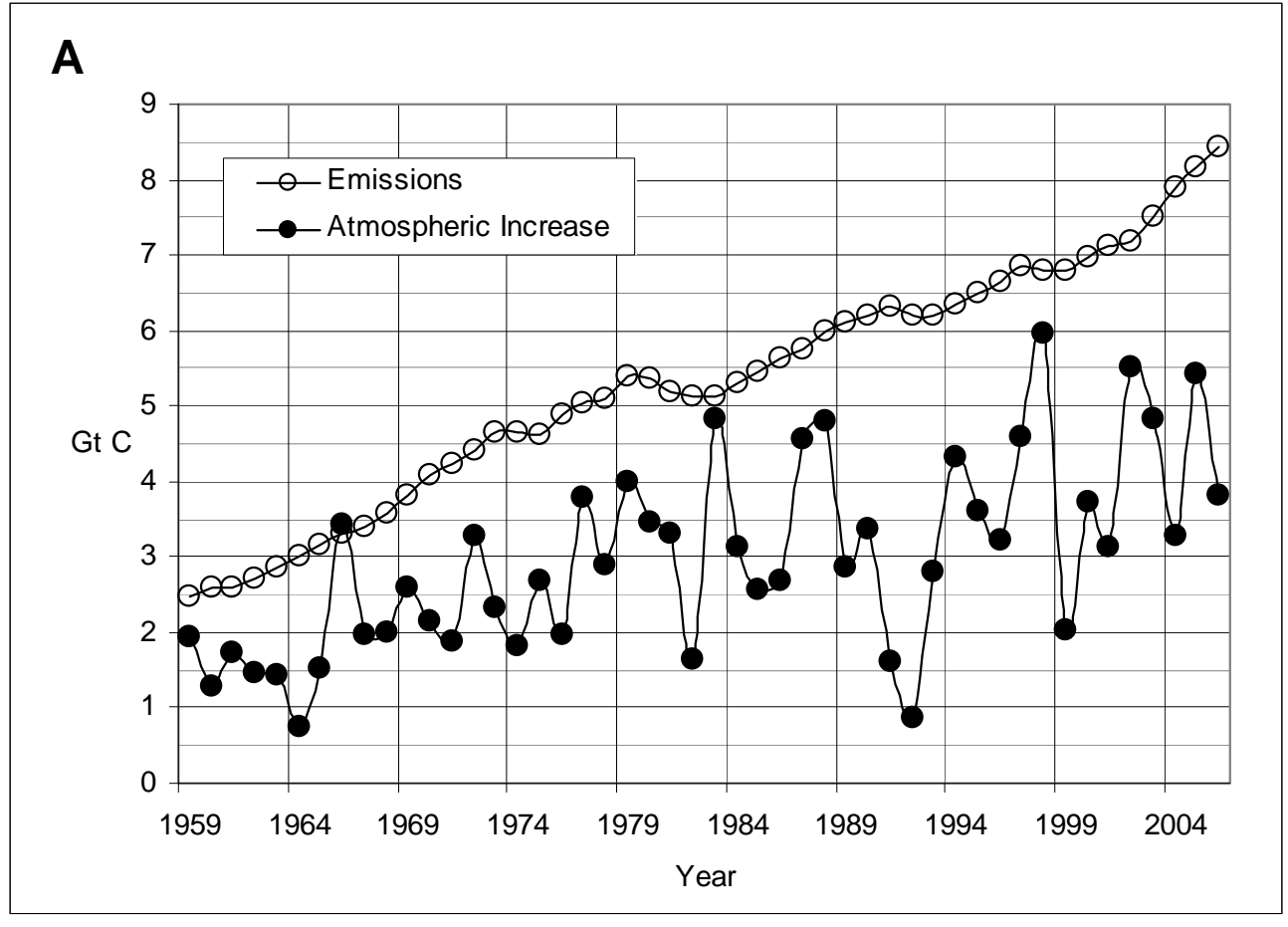

$\mathbf{B}$

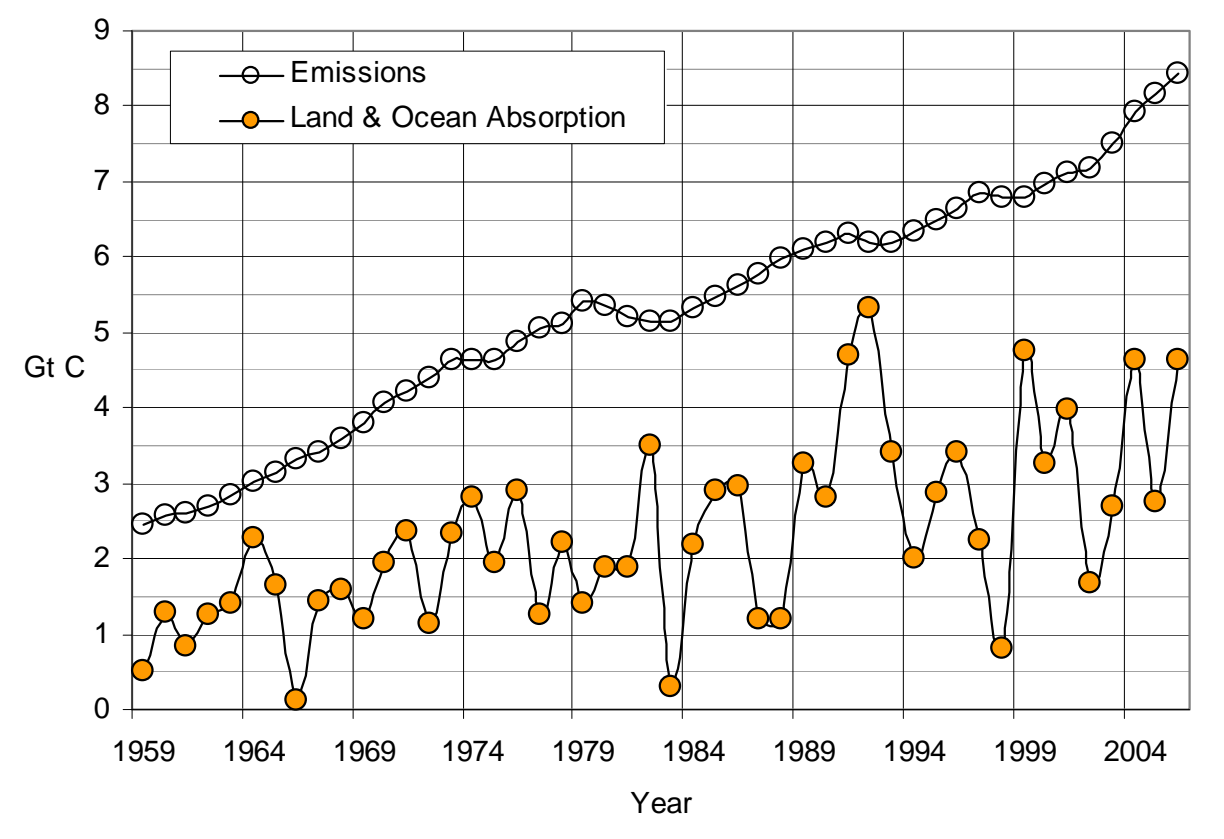

Figure 1 A) Estimated emissions from worldwide fossil fuel use and the annual increase in atmospheric $\mathrm{CO}_{2}$ sourced from http://cdiac.ornl.gov/trends/co2/contents.htm . B) Estimated emissions from worldwide fossil fuel use and the estimated amount of CO2 absorbed by land and ocean, calculated by subtraction of the atmospheric CO2 increase from the estimated emissions from fossil fuels. 
The justification for this conclusion is supported by measurements of the falling proportion of ${ }^{13} \mathrm{C}$ in the atmosphere which is taken to signal the appearance of $\mathrm{CO}_{2}$ from fossil fuel emissions.

The fundamental assumption of the anthropogenic source of increasing $\mathrm{CO}_{2}$ is the basis for all climate change policy development. It has deep historical roots given fresh force from measurements started in the late 1950's. Extended time series data have become available and it is well worth reviewing the data to check that original assumptions remain valid.

Carbon has two stable isotopes, Carbon- $12\left({ }^{12} \mathrm{C}\right)$ and Carbon- $13\left({ }^{13} \mathrm{C}\right)$. In general ${ }^{12} \mathrm{C}$ is $99 \%$ of natural carbon and ${ }^{13} \mathrm{C} 1 \%$. However the rates at which chemical reactions and physical processes take place vary due to the masses of the isotopes present. For carbon the result is fractionation of the isotopes so that carbon found in coal or oil is $1.083 \%{ }^{13} \mathrm{C}$ while carbon in the atmosphere is $1.103 \%{ }^{13} \mathrm{C}$.

Results are given as $\boldsymbol{\delta}^{13} \mathrm{C}$, a measure of the isotope ratio of ${ }^{13} \mathrm{C} /{ }^{12} \mathrm{C}$ defined as:

$$
\boldsymbol{\delta}=1000 \times\left(\left({ }^{13} \mathrm{C} /{ }^{12} \mathrm{C}\right)_{\text {sample }} /\left({ }^{13} \mathrm{C} /{ }^{12} \mathrm{C}\right)_{\text {standard }}-1\right)
$$

The standard ratio is an international standard of comparison and is the zero point for $\delta{ }^{4}$.

$\delta$ for $\mathrm{CO}_{2}$ coming from biogenic sources has an approximate value of $-26^{5}$, the fossil fuel value is 29 , (estimated from US energy use ${ }^{6}$ from a range of -20 to -44 ) and $\mathrm{CO}_{2}$ from the ocean is given values ranging from -7 to $1.5^{7}$. The atmospheric values are found to vary from -7 to -8 . If there are two sources of $\mathrm{CO}_{2}$, the ocean and a biogenic or fossil fuel source then the average implies that some $4 \%$ to $33 \%$ of atmospheric $\mathrm{CO}_{2}$ has been derived from biogenic or fossil fuel sources ${ }^{8}$.

One of the great unknowns is the variability of the oceans that have multi-year cycles that cause temperature variations such as El Nino and the Southern Oscillation events. It is not clear whether there are other climate effects from the oceans and from the land and ocean based sources of biogenic $\mathrm{CO}_{2}$. However the size of these reservoirs and the annual exchanges with the atmosphere are estimated to be at least a factor of 20 times the annual production of $\mathrm{CO}_{2}$ from fossil fuel ${ }^{9}$. There are substantial uncertainties in reservoir size and exchanges.

This paper provides an analysis of the changes in $\mathrm{CO}_{2}$ and ${ }^{13} \mathrm{C}$ in the atmosphere using the extensive measurements made by the $\mathrm{SIO}^{10}$ and the $\mathrm{CSIRO}^{11}$ spanning many years. All the data are available on the website http://cdiac.ornl.gov/trends/co2/contents.htm with $\mathrm{CO}_{2}$ concentrations and ${ }^{13} \mathrm{C} /{ }^{12} \mathrm{C}$ isotope ratios in monthly and yearly form ${ }^{12,14}$. The development of this extensive set of measurements has been reviewed recently by Beck ${ }^{13}$.

Three approaches have been adopted, first looking directly at the variations of ${ }^{13} \mathrm{C}$ in the atmosphere, second, looking at the seasonal variations of $\mathrm{CO}_{2}$ through the annual summer-winter cycles and finally examining timing differences of the Northern and Southern Hemisphere changes in $\mathrm{CO}_{2}$.

\section{CARBON-13 IN THE ATMOSPHERE}

Variations in the amount of ${ }^{13} \mathrm{C}$ in $\mathrm{CO}_{2}$ are shown in Figures 2 and 3 with data from the Scripps Institute of Oceanography (SIO) for Mauna Loa and also the South Pole ${ }^{14}$. 
Variations in ${ }^{13} \mathrm{C}$ have a strong cyclic pattern in the Northern Hemisphere with a biogenic variation in ${ }^{13} \mathrm{C}$ as plant growth preferentially favours the lighter isotope, ${ }^{12} \mathrm{C}$.

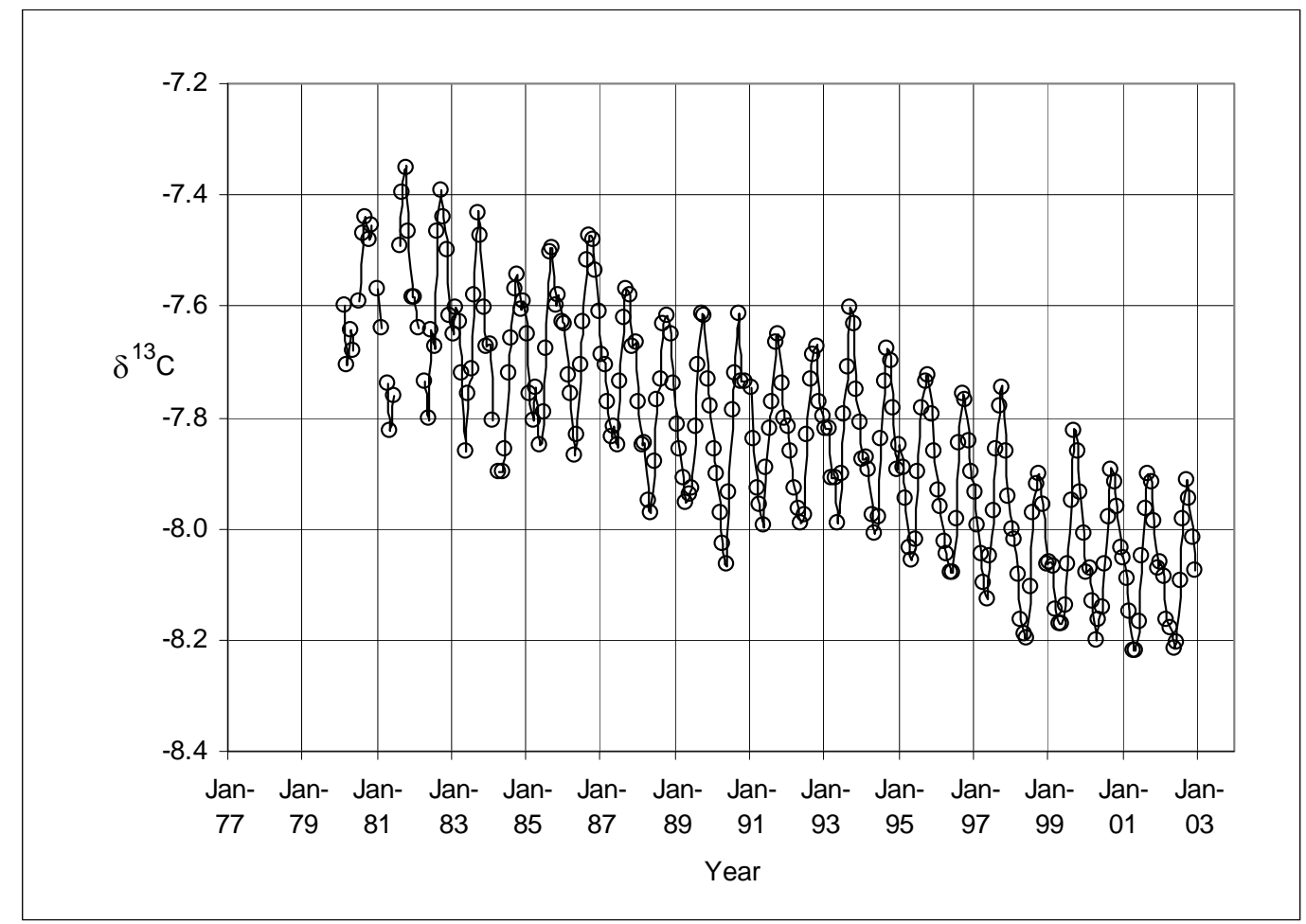

Figure 2 Monthly variations in $\delta^{13} \mathrm{C}$ at Mauna Loa from $\mathrm{SIO}^{14}$

However at the South Pole this variation is muted and it is possible to see trends outside of the annual variations.

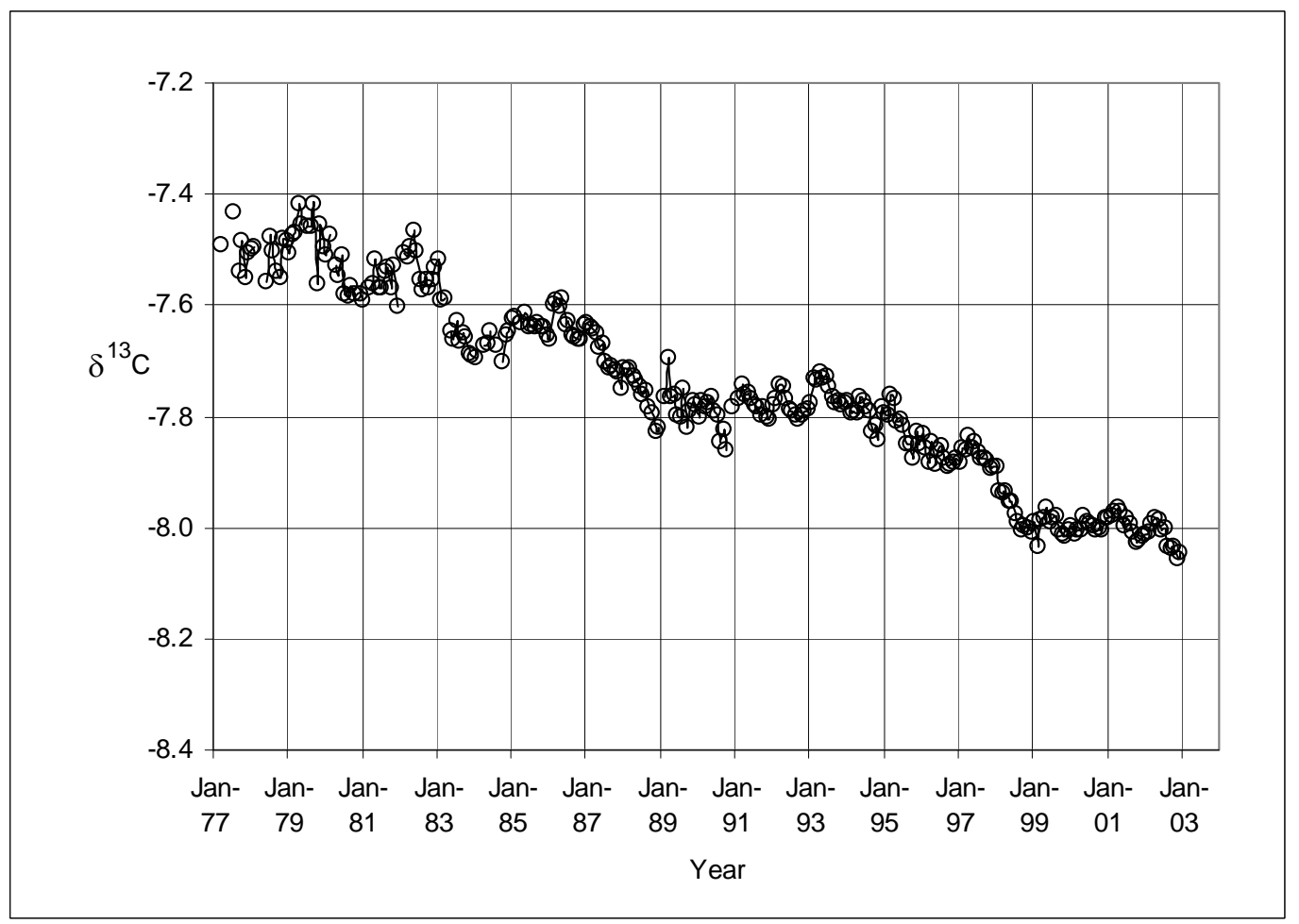

Figure 3 Monthly variations in $\delta^{13} C$ at the South Pole from SIO ${ }^{14}$

The measurements show a cascade of values with the atmosphere showing a decrease in ${ }^{13} \mathrm{C}$. In fact the fall in ${ }^{13} \mathrm{C}$ appears as a series of steps. This behaviour is better displayed by looking at annual changes. Figure 4 shows these changes for SIO measurements from Mauna Loa and the South Pole. The annual differences in $\delta^{13} \mathrm{C}$ are calculated from three month averages of year on year differences 
of the monthly measured values in order to remove the regular seasonal cycle and to expose departures from that cycle.

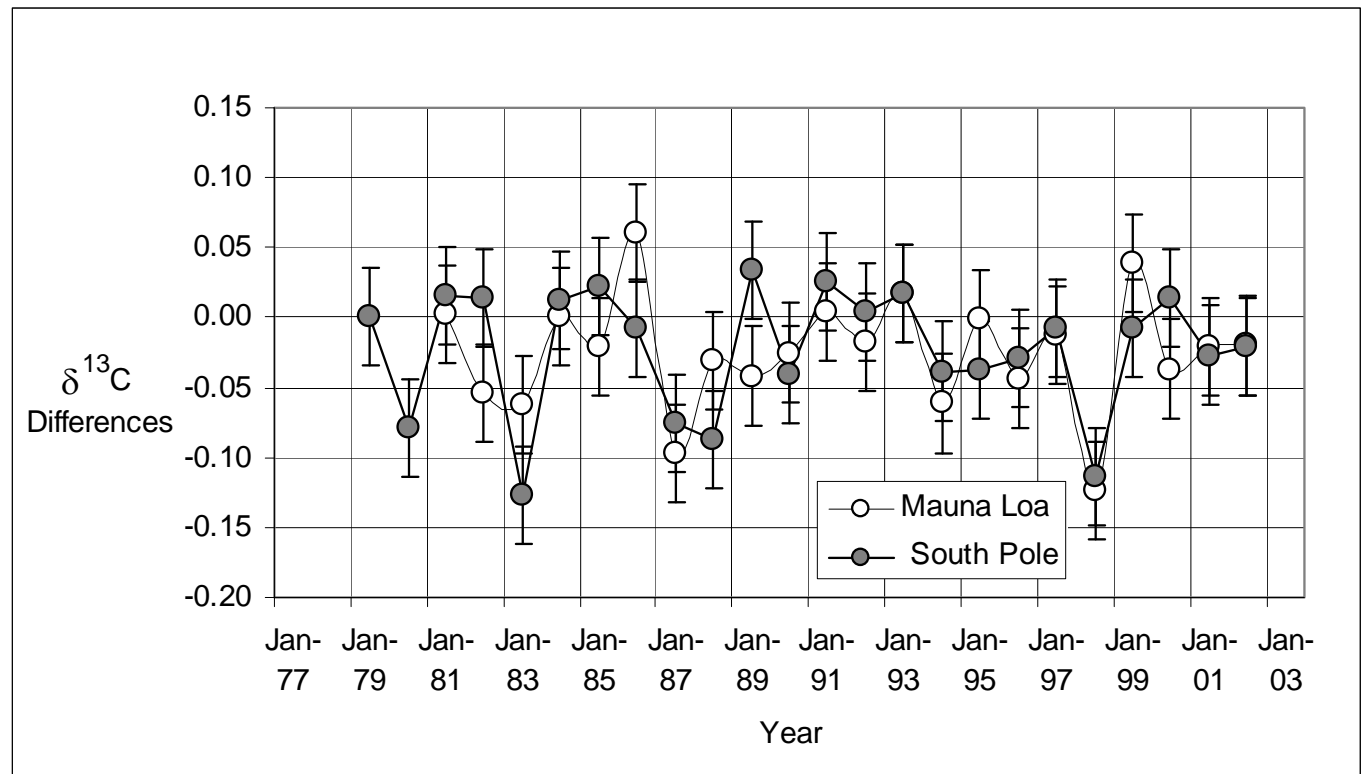

Figure 4 Three Month averages of year on year differences of the monthly measured $\delta^{13} C$ for Mauna Loa and the South Pole ${ }^{14}$.

A natural question to ask is whether these steps are associated with other variations in the atmosphere. The annual increase in $\mathrm{CO}_{2}$ is shown in Figure 5 taking one-year differences from each location time series thus again removing a regular seasonal cycle to expose departures from that cycle.

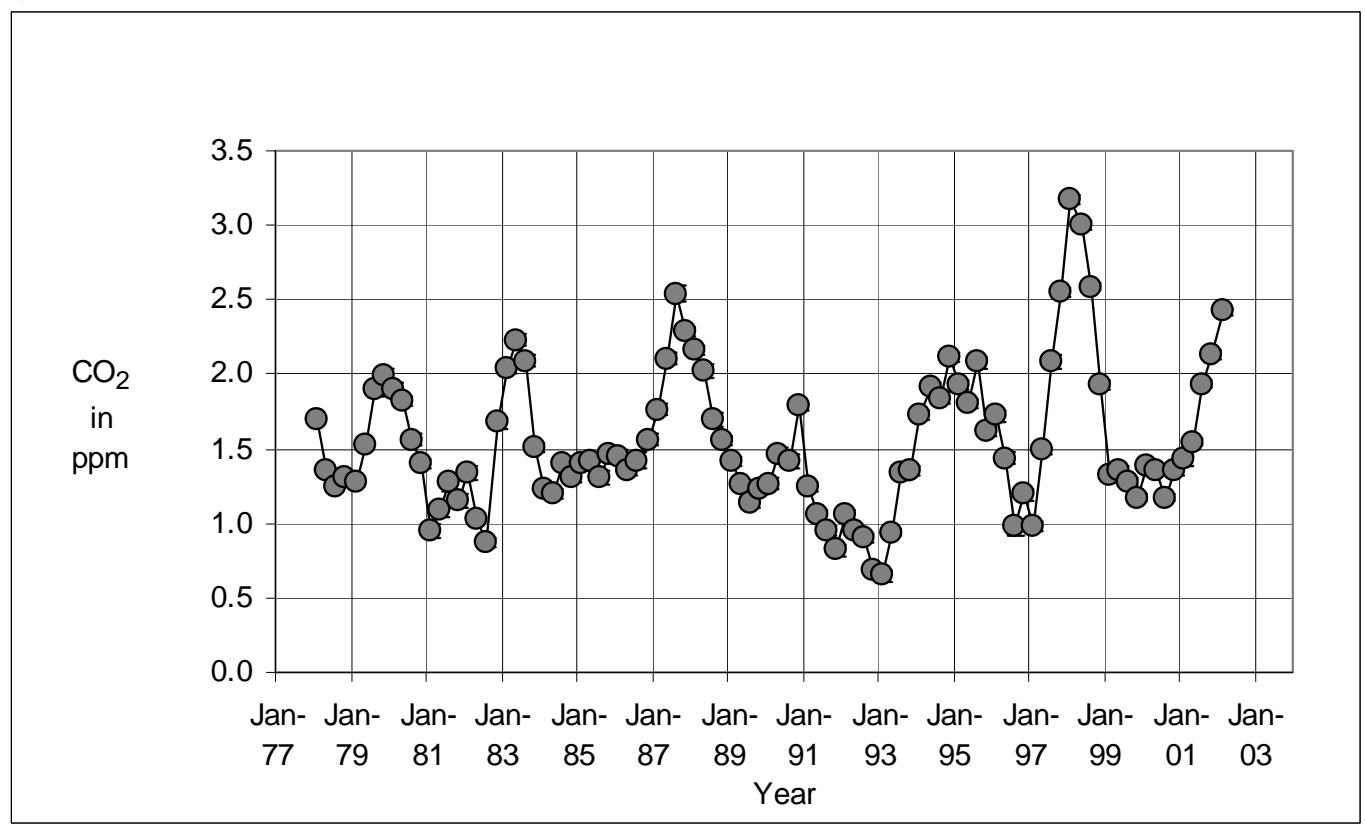

Figure 5 Three Month averages of year on year differences of the monthly measured CO2 atmospheric concentrations for Mauna Loa and the South Pole ${ }^{2}$.

Following the pattern shown in Figures 4 and 5, all 15 available data sets of ${ }^{13} \mathrm{C}$ measurements have been analysed. These extend from $82^{\circ} \mathrm{N}$ at Alert to $90^{\circ} \mathrm{S}$ at the South Pole. The results are shown in Figure 6. The same differencing procedure discussed above has been applied to the changes in ${ }^{13} \mathrm{C}$ 


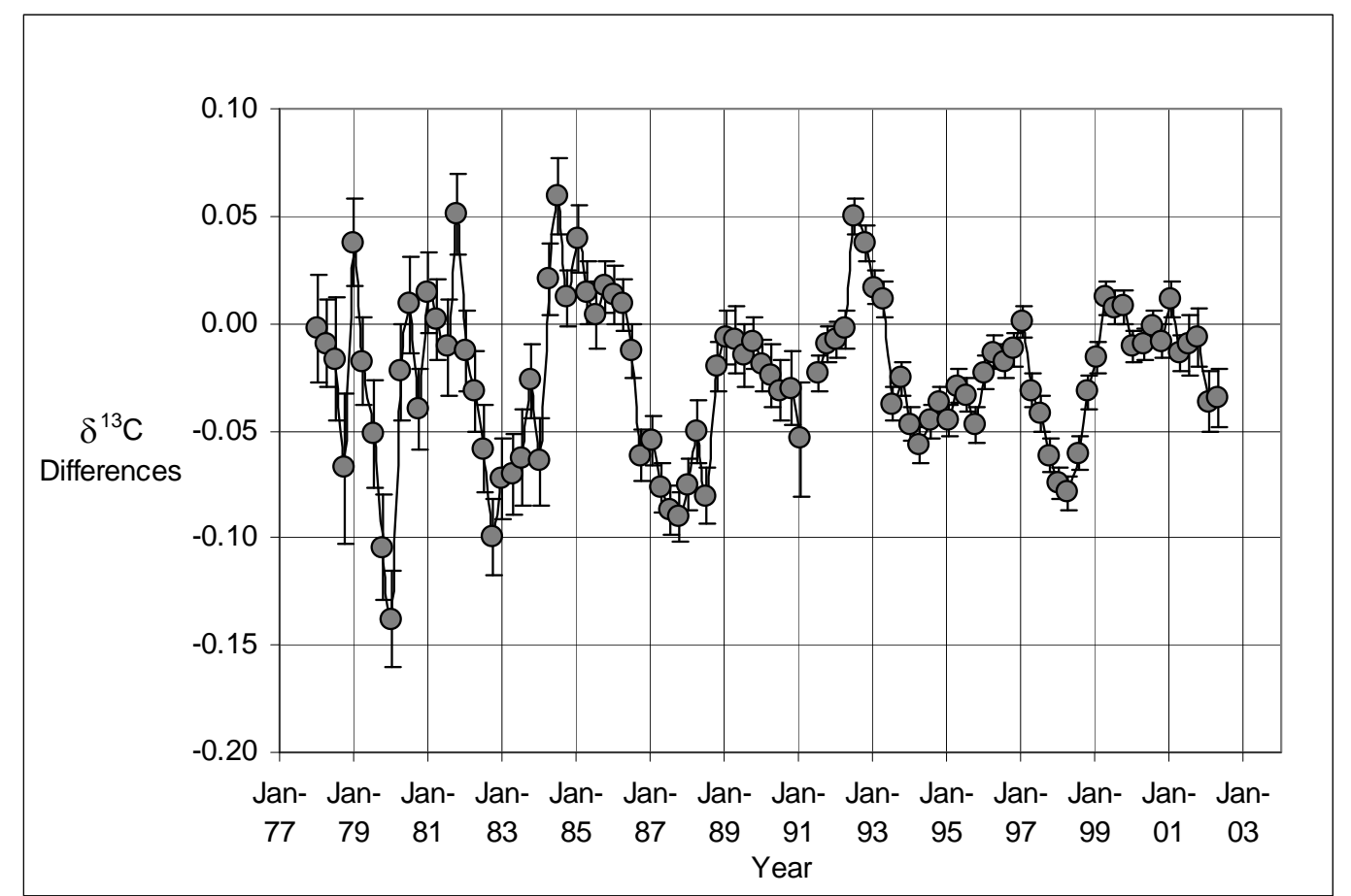

Figure 6 Three Month averages of year on year differences of the monthly measured $\delta^{13} \mathrm{C}$ from $\mathrm{SIO}^{14}$ and $\mathrm{CSIRO}^{12}$ data for 15 locations from Alert to the South Pole. Error bars are errors of the mean.

The location data sets have been combined on the assumption that variations in ${ }^{13} \mathrm{C}$ are simultaneous throughout the atmosphere within the accuracy of the data.

There is a discontinuity in the SIO data at the start of $1991^{15}$. The step in the SIO data and its difference to the CSIRO data is shown in Figure 7. In Figure 6 and all subsequent analysis the SIO data for 1991 has not been used.

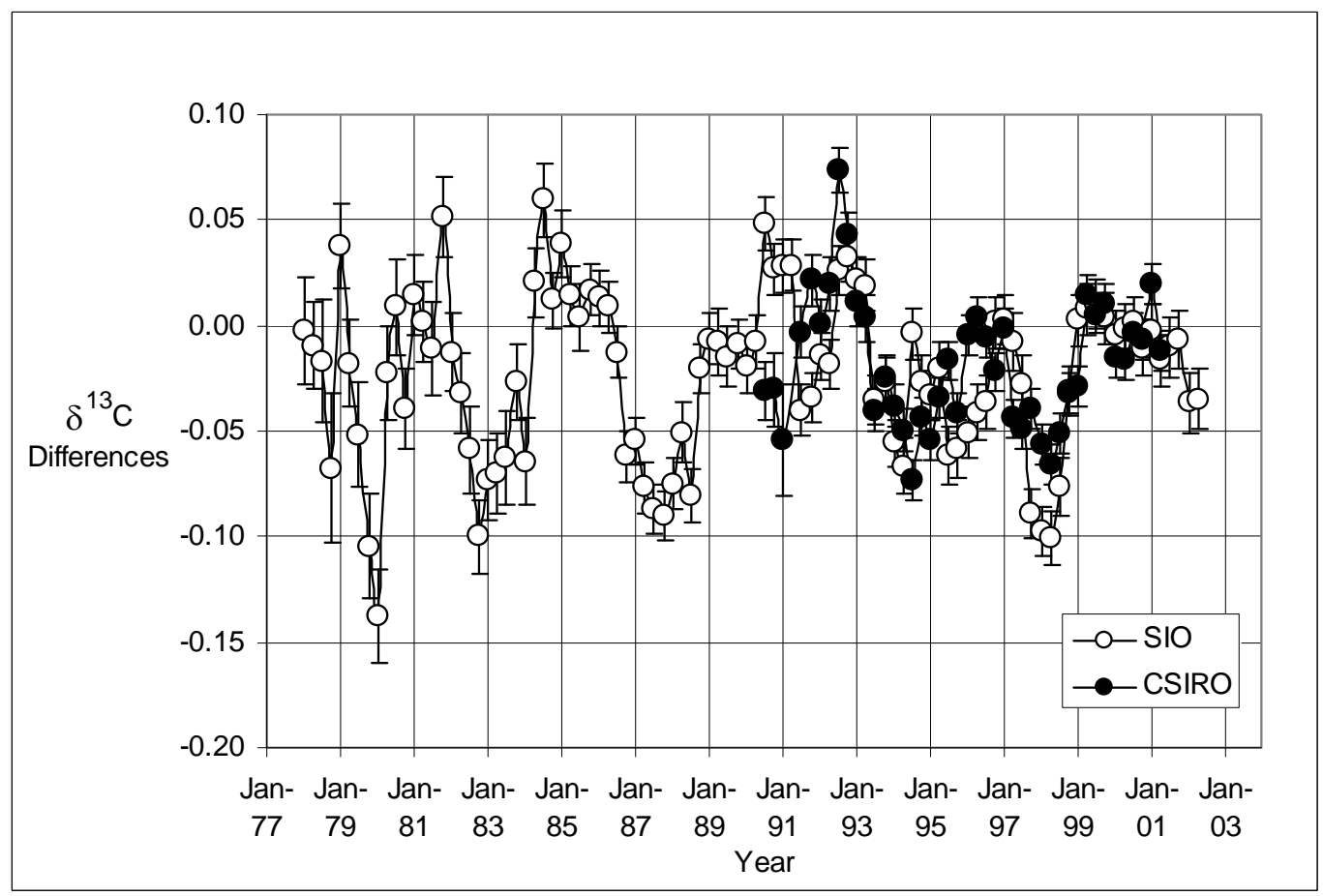

Figure 7 Separate SIO and CSIRO data series. Three Month averages of year on year differences of the monthly measured $\delta^{13} \mathrm{C}$ from $\mathrm{SIO}^{14}$ and CSIRO ${ }^{12}$ data for 15 locations from Alert to the South Pole. Error bars are errors of the mean. 
The measuring errors combined with any time spread have been estimated by looking at the spread of measurements at each time point with from 1 to 15 locational data points. The standard deviation is found to be overall 0.050 for $\delta{ }^{13} \mathrm{C}$ with 0.050 for the SIO data and 0.046 for the CSIRO data.

The errors plotted are the errors on the mean. Some 2,000 data points have been used in the analysis and a small number, less than 30 , were rejected as being more than 4 standard deviations from the mean. This was a particular problem in the 1991-92 period where 22 SIO data points were rejected.

The correlation of $\mathrm{CO}_{2}$ concentration with $\delta^{13} \mathrm{C}$ gives a correlation coefficient of -0.60 . Figure 8 illustrates this correlation where the $\delta^{13} \mathrm{C}$ difference values have been plotted along with the annual changes in $\mathrm{CO}_{2}$ concentration.

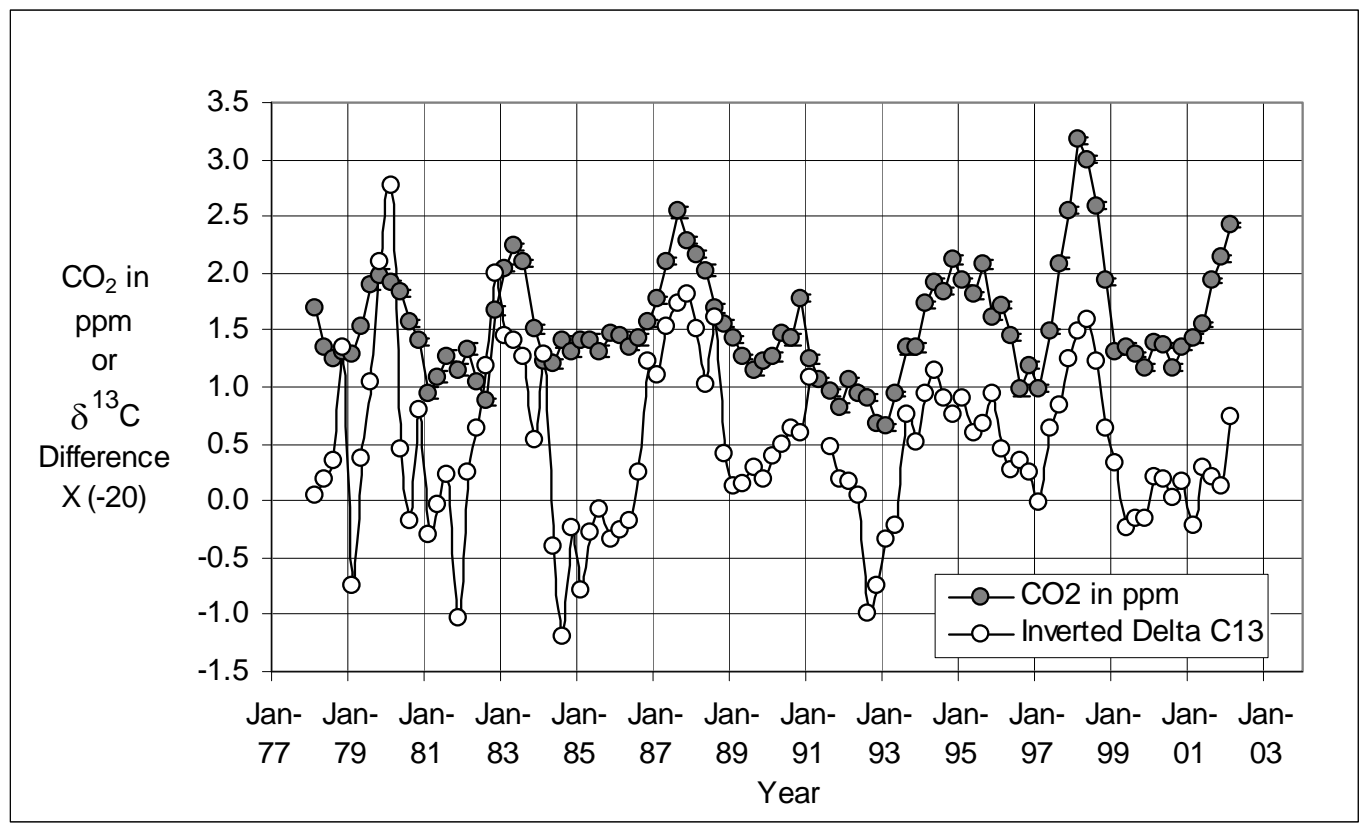

Figure 8 Correlation of CO2 annual increases and $\delta^{13} C$ differences. The $\delta^{13} C$ differences have been inverted and scaled. Three Month averages of year on year differences of the monthly measured $\mathrm{CO}_{2}$ concentrations for Mauna Loa and the South Pole ${ }^{2}$ and $\delta^{13} \mathrm{C}$ from $\mathrm{SIO}^{14}$ and CSIRO $^{12}$ data for 15 locations from Alert to the South Pole.

The peaks in the $\mathrm{CO}_{2}$ concentration appear to correlate with $\mathrm{ENSO}^{16}$ events of Figure 9.

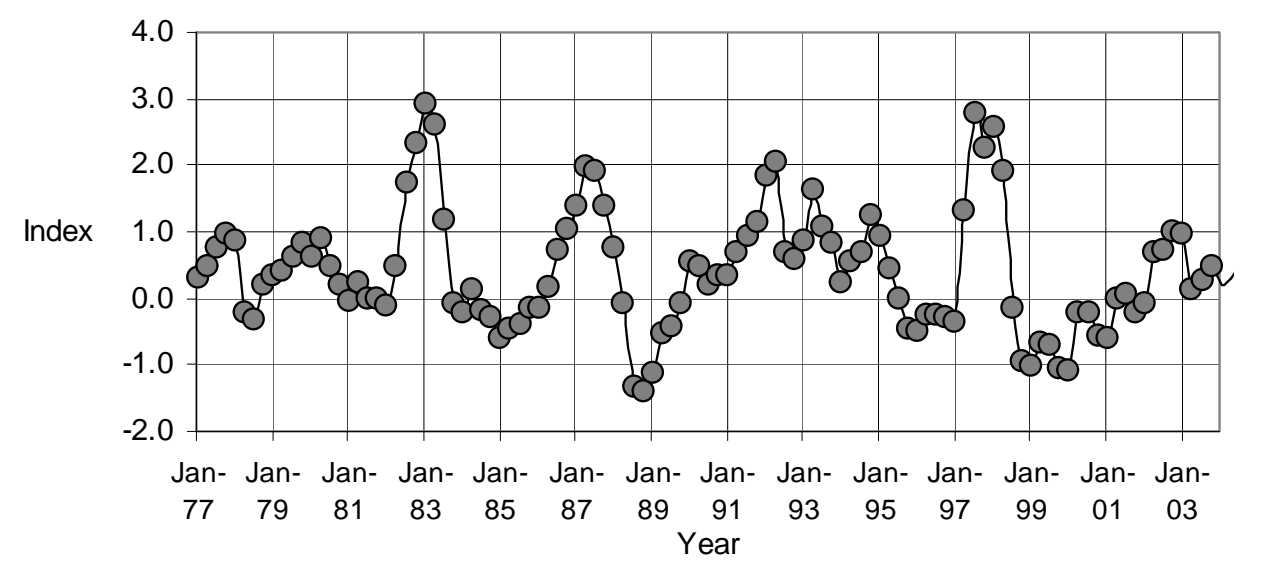

Figure 9 Multivariate ENSO Index compiled by $K$ Walter $^{16}$

So this would suggest that the change in $\delta^{13} \mathrm{C}$ might be driven from the same source responsible for ENSO events. 


\section{ILLUSTRATION OF CARBON-13 CASCADE}

In order to illustrate the working of the analysis, a simple set of straight lines have been matched to the South Pole data points as shown in Figure 10. The alternative of a constant addition of fossil fuel $\mathrm{CO}_{2}$ would give a steady decrease in $\delta^{13} \mathrm{C}$. The yearly differences (Figure 11) show the mapping of the $\delta{ }^{13} \mathrm{C}$ cascade.

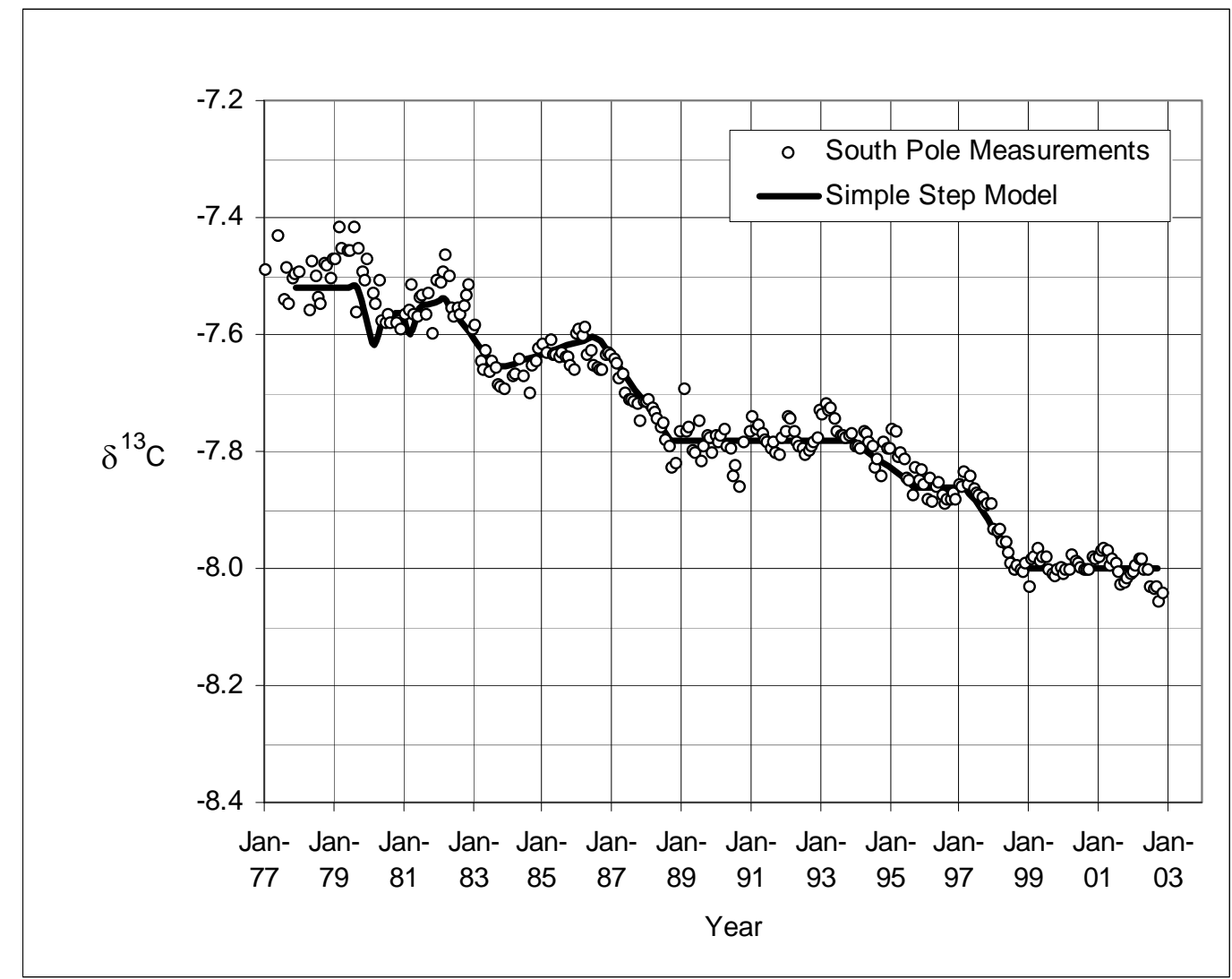

Figure $10 \mathrm{~A}$ simple step model of the changes in $\delta^{13} \mathrm{C}$ at the South Pole compared to the SIO measurements.

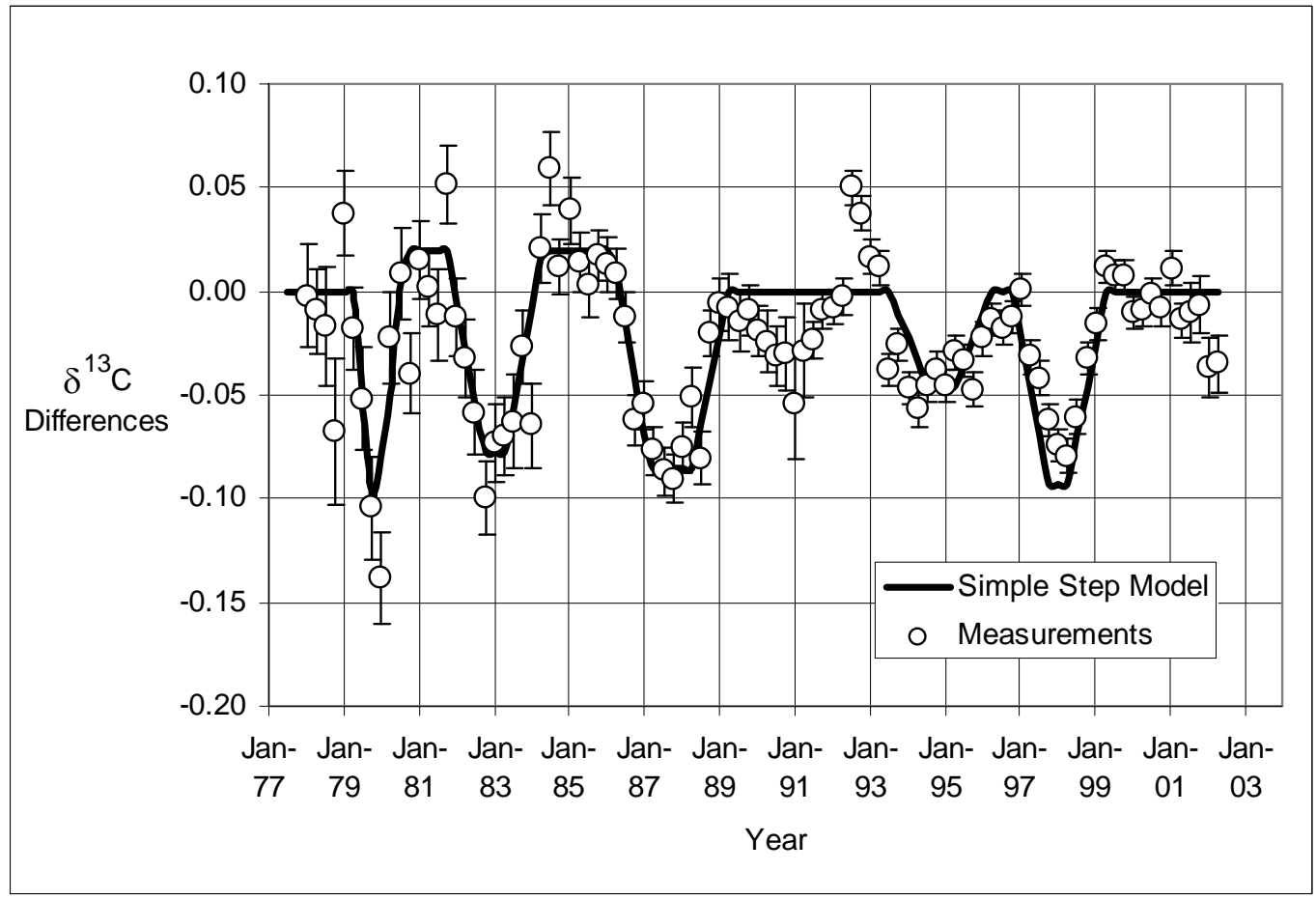

Figure 11 A simple step model of the changes in $\delta^{13} C$ at the South Pole along with the SIO measurements showing annual differences in $\delta^{13} C$. 
The correlation of changes in $\delta^{13} \mathrm{C}$ with ENSO events and the comparison with a simple model of a series of cascades suggest that the changes in $\delta^{13} \mathrm{C}$ in the atmosphere have little to do with the input of $\mathrm{CO}_{2}$ emissions from the continuous use of fossil fuels.

\section{SEASONAL VARIATIONS OF ATMOSPHEREIC CARBON DIOXIDE}

The increase of $\mathrm{CO}_{2}$ in the atmosphere is modulated by seasonal variations. These are understood to be a reflection of biogenic and chemical interactions from plants, the soil and the oceans. There is a remarkable regularity in this as can be seen in Figure 12 for the monthly measurements at Mauna Loa.

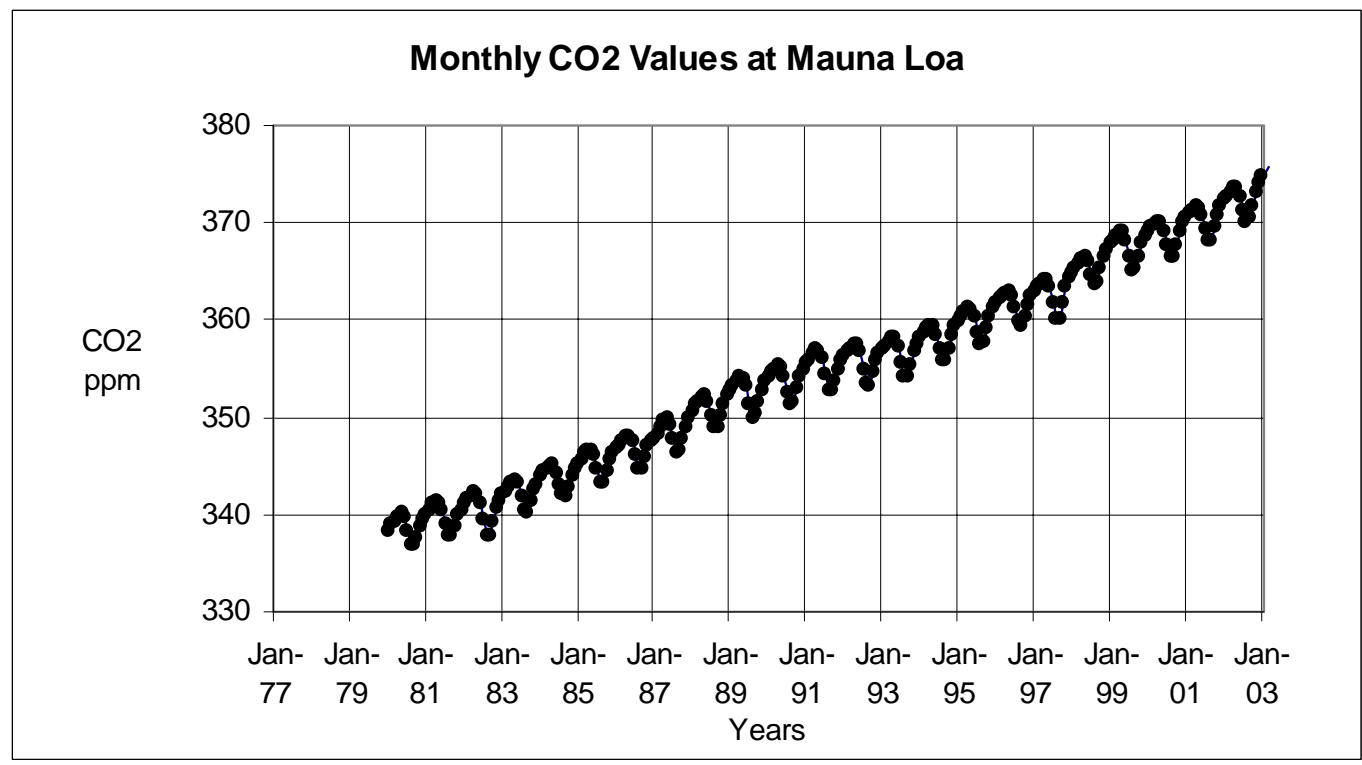

Figure 12 Monthly variations of CO2 concentration at Mauna $\mathrm{Loa}^{2}$.

The variations of $\mathrm{CO}_{2}$ in the atmosphere over the last twenty-five years are best summarised in the following figures 13, 14 and 15 with the results listed in the Attachment. The data is from the extensive SIO and CSIRO measurements of $\mathrm{CO}_{2}$ and from one UBA site, Schauinsland in Germany $^{17}$.

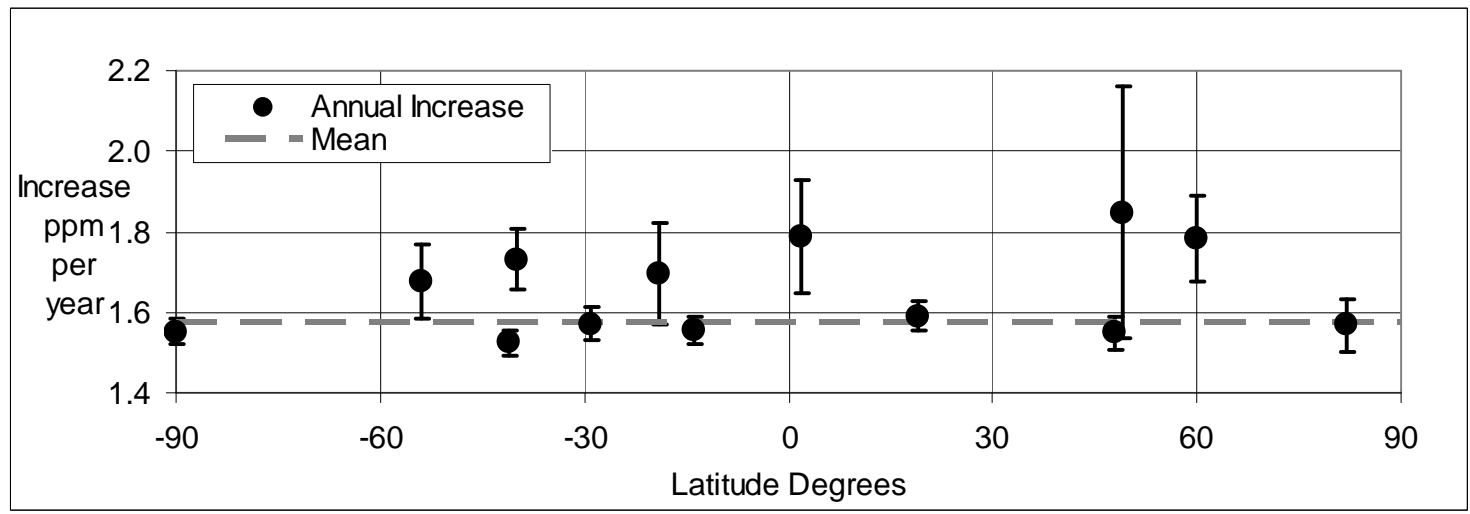

Figure 13 Annual increases in $\mathrm{CO}_{2}$ concentration at different locations. The time span ranges from 7 to 22 years.

The annual increase of $\mathrm{CO}_{2}$ in the atmosphere is in sharp contrast with the annual change in the seasonal variations. The mean values are:

$$
\begin{array}{lr}
\text { Annual } \mathrm{CO}_{2} \text { increase } & 1.572 \pm 0.013 \mathrm{ppm} \text { per year } \\
\text { Seasonal } \mathrm{CO}_{2} \text { increase } & -0.001 \pm 0.013 \mathrm{ppm} \text { per year }
\end{array}
$$

There is a difference, within errors, of a factor of 100 in annual increases. 


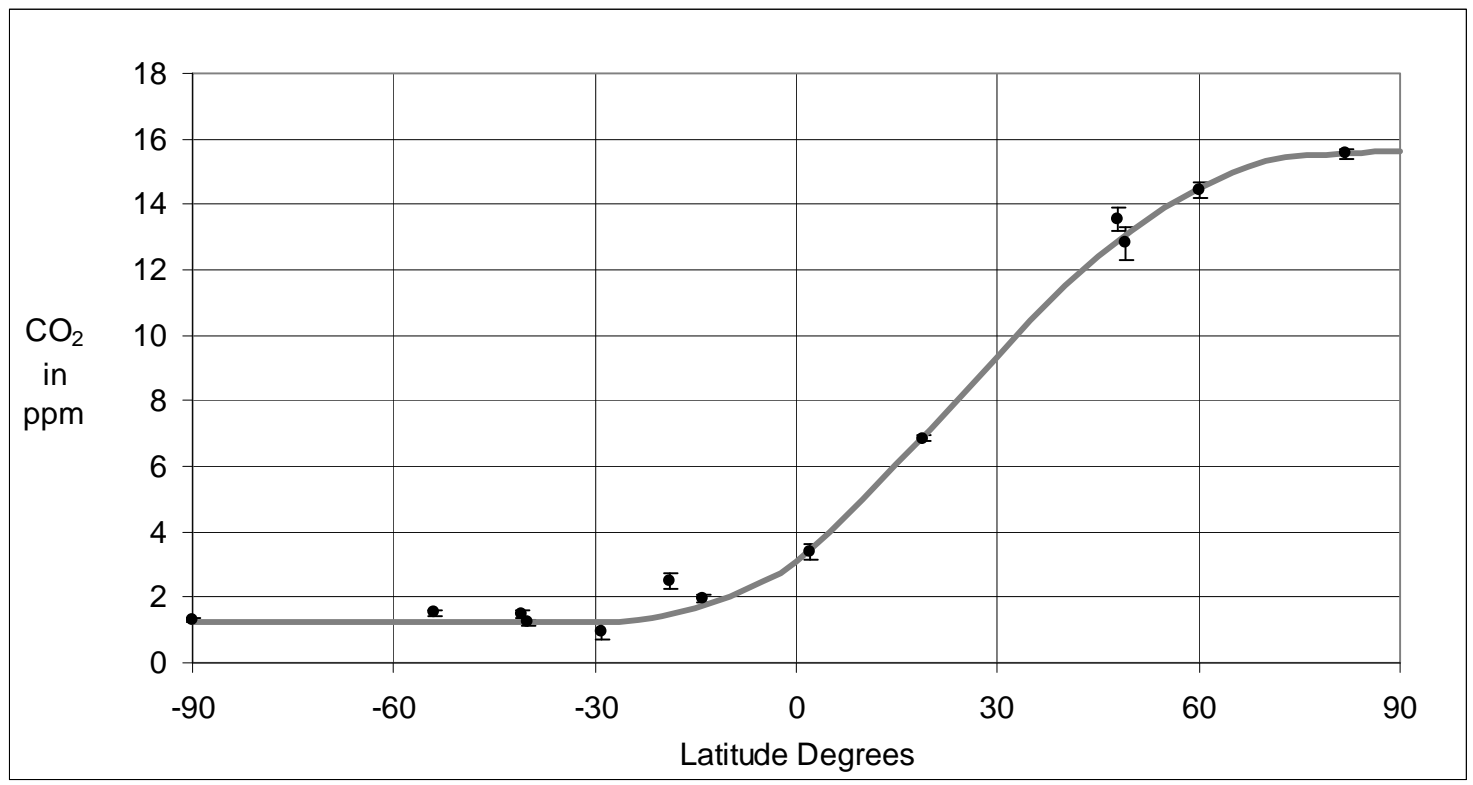

Figure 14 Seasonal variations of $\mathrm{CO}_{2}$ concentration at different locations. The time span ranges from 7 to 22 years.

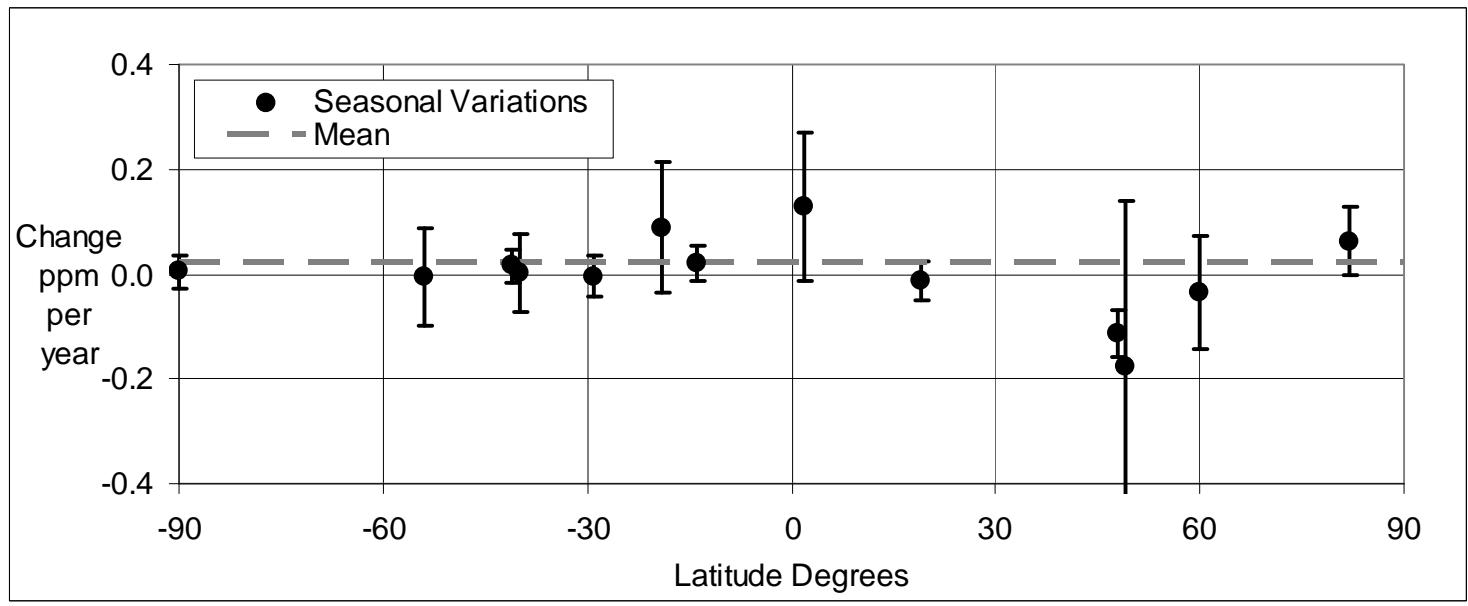

Figure 15 Annual changes in the seasonal variation of $\mathrm{CO}_{2}$ concentration at different locations. The time span ranges from 7 to 22 years.

Over the last 20 years substantial amounts of $\mathrm{CO}_{2}$ derived from fossil fuel have been released into the atmosphere. This has moved from $5.0 \mathrm{Gt}$ of carbon in 1980 to $6.2 \mathrm{GtC}$ in 1990 to $7.0 \mathrm{GtC}$ in 2000. Figure 16 shows the distribution of fossil fuel $\mathrm{CO}_{2}$ by latitude ${ }^{18}$.

Over $95 \%$ of this $\mathrm{CO}_{2}$ has been released in the Northern Hemisphere.

To put this in context, the total carbon in $\mathrm{CO}_{2}$ in that region of the atmosphere is some $400 \mathrm{GtC}$ with seasonal net variations of $10 \mathrm{GtC}$. (This can be seen in Figure 14 where the mean seasonal net variation is $9 \mathrm{ppm}$ for a total $380 \mathrm{ppm} \mathrm{CO}_{2}$ concentration.)

The remarkable feature of this behaviour is that despite the accumulation in the atmosphere of fossil fuel emissions from 1980 to 2000 at the rate $3 \mathrm{GtC}$ per year, there has been virtually no change in the seasonal variations.

If the rise in $\mathrm{CO}_{2}$ concentration is understood to be from fossil fuel $\mathrm{CO}_{2}$ but the balance of emissions is taken up by sinks of $\mathrm{CO}_{2}$ then it follows that there is an increase in the capacity of the 


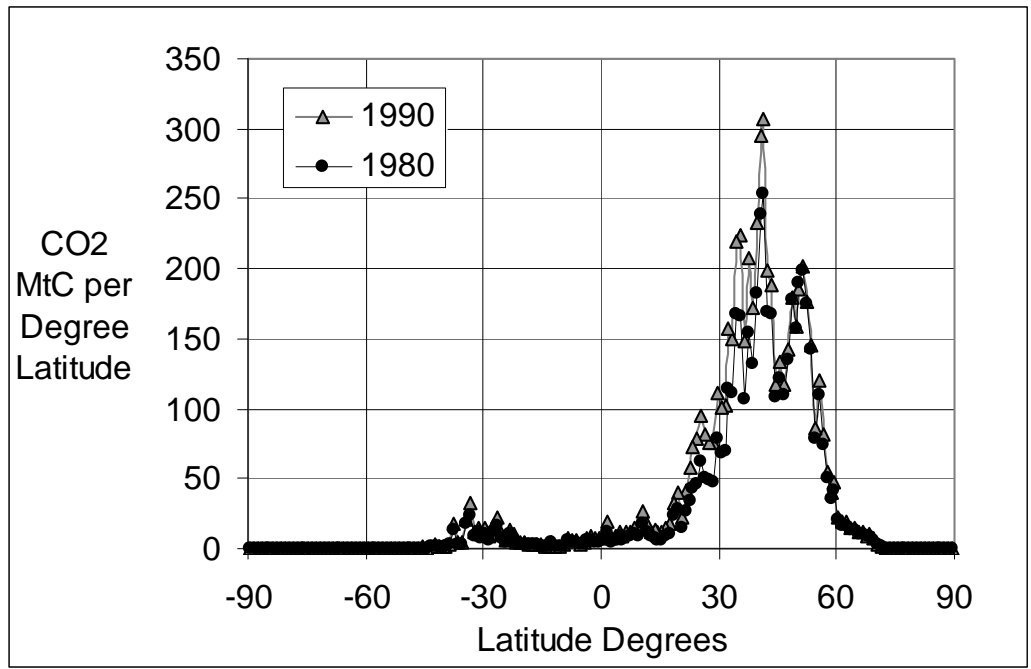

Figure 16 Estimated Atmospheric CO2 from fossil fuels. Source CDIAC ${ }^{18}$.

sinks to absorb $\mathrm{CO}_{2}$. If this is the case then one might expect changes in the seasonal variations in proportion to the expansion of the land-based or biogenic sinks of $\mathrm{CO}_{2}$.

The estimate of the effects of added $\mathrm{CO}_{2}$ is shown for the Northern Hemisphere in Table 1. The carbon cycle data is taken from the $3^{\text {rd }}$ IPCC Report ${ }^{19}$.

\begin{tabular}{|c|c|c|c|c|c|c|}
\hline \multirow{2}{*}{\multicolumn{2}{|c|}{ Carbon Cycle }} & & \multicolumn{2}{|c|}{ Atmosphere } & \multicolumn{2}{|c|}{$\begin{array}{l}\mathrm{CO}_{2} \text { from } \\
\text { Fossil Fuel }\end{array}$} \\
\hline & & & 1980 & 2000 & 1980 & 2000 \\
\hline \multicolumn{7}{|l|}{ Global } \\
\hline Atmospheric Concentration of $\mathrm{CO}_{2}$ & ppm & \multirow{3}{*}{1.572} & 350 & 381 & \multirow{11}{*}{5.30} & \multirow[b]{6}{*}{7.00} \\
\hline Increase per year & ppm & & & & & \\
\hline Amount of $\mathrm{CO}_{2}$ in Atmosphere Tonnes & GtC & & 750.0 & 816.4 & & \\
\hline Total Atmosphere $\mathrm{CO}_{2}$ Exchanges & GtC & $28 \%$ & 210.0 & 228.6 & & \\
\hline Atmosphere-Land $\mathrm{CO}_{2}$ Exchanges & $\mathrm{GtC}$ & $16 \%$ & 120.0 & 130.6 & & \\
\hline Increase per year & GtC/year & & 3.4 & 3.4 & & \\
\hline \multicolumn{2}{|l|}{$\begin{array}{l}\text { Northern Hemisphere } \\
\text { Atmosphere Fraction }\end{array}$} & \multirow[t]{2}{*}{$50 \%$} & & & & \\
\hline Amount of $\mathrm{CO}_{2}$ Tonnes & GtC & & 375.0 & 408.2 & & \\
\hline Atmosphere-Land $\mathrm{CO}_{2}$ Exchanges & GtC & \multirow[t]{3}{*}{$22 \%$} & 80.6 & 87.8 & & \\
\hline Net Seasonal Variations & ppm & & 9.4 & 9.4 & & \\
\hline$\sim 12 \%$ of land exchanges & $\mathrm{GtC}$ & & 10.1 & 10.1 & & \\
\hline \multirow{4}{*}{$\begin{array}{l}\text { Fossil Fuel } \mathrm{CO}_{2} \text { Emitted } \\
\text { Land source/sink } \\
\text { Emitted } \mathrm{CO}_{2} \text { absorbed by land sink } \\
\text { Increase to Seasonal Variations } \\
\quad \sim 12 \% \text { of additional absorbed } \mathrm{CO}_{2}\end{array}$} & GtC & $100 \%$ & & & 5.30 & 7.00 \\
\hline & GtC & \multirow[t]{3}{*}{$30 \%$} & & & 1.59 & 2.10 \\
\hline & GtC & & & & \multirow[t]{2}{*}{0.20} & \multirow[t]{2}{*}{0.24} \\
\hline & & & & & & \\
\hline $\begin{array}{l}\text { Estimated Increase per year } \\
\text { Seasonal Variations }\end{array}$ & ppm & & & & 0.185 & 0.225 \\
\hline $\begin{array}{l}\text { Measured Increase per year } \\
\text { Seasonal Variations } \\
(-0.001+/-0.013)\end{array}$ & ppm & & & & 0.013 & 0.013 \\
\hline
\end{tabular}

Table 1 Estimate of expected increase in seasonal variations for CO2 in the Northern Hemisphere. The third column shows the seasonal variations for 1980 and 2000. The fourth column shows the estimated contribution from the continuous production of fossil fuel $\mathrm{CO}_{2}$ for 1980 and 2000. The $\mathrm{CO}_{2}$ from fossil fuel is assumed to be distributed 50\% to the atmosphere, 20\%, to the ocean and $30 \%$ to biogenic sinks. In the Northern Hemisphere the land exchange has been increased as there is $40 \%$ land cover compared to $20 \%$ for the Southern Hemisphere. 
The calculations in the tables are order of magnitude estimates of the variations that might be expected if $30 \%$ of the fossil fuel sourced $\mathrm{CO}_{2}$ was taken up in biogenic sinks.

In addition there is a $10 \%$ seasonal variation in $\mathrm{CO}_{2}$ from fossil fuel use in North America and a similar behaviour might be expected in Europe. These variations have not been considered.

The estimates indicate limits to the variations that are substantially larger than the measured values. This assumes that the measured value is independent of latitude.

It is remarkable that emitted $\mathrm{CO}_{2}$ is thought to be partially absorbed by $\mathrm{CO}_{2}$ sinks but yet leaves no hint of expected biogenic variation. Increasing $\mathrm{CO}_{2}$ might be expected to encourage plant growth. A simple conclusion that might be drawn from this is that the fossil fuel derived $\mathrm{CO}_{2}$ is almost totally absorbed locally in the year that it is emitted. An alternative explanation would require the ocean to be the sink for $\mathrm{CO}_{2}$. The absence of change remains a puzzle.

\section{NORTH-SOUTH HEMISPHERE TIMING DIFFERENCES}

Another interesting approach is to see if there are timing differences between the Northern and Southern Hemispheres (NH and $\mathrm{SH}$ ) with the emission of $\mathrm{CO}_{2}$.

A tracer for $\mathrm{CO}_{2}$ transport from the $\mathrm{NH}$ to the $\mathrm{SH}$ was provided by. ${ }^{14} \mathrm{C}$ created by nuclear weapons testing in the 1950's and 1960's. The analysis of ${ }^{14} \mathrm{C}$ in atmospheric $\mathrm{CO}_{2}{ }^{20},{ }^{21}$ shows in Figure 17 that it took some years for exchanges of $\mathrm{CO}_{2}$ between the hemispheres before the ${ }^{14} \mathrm{C}$ was uniformly distributed.

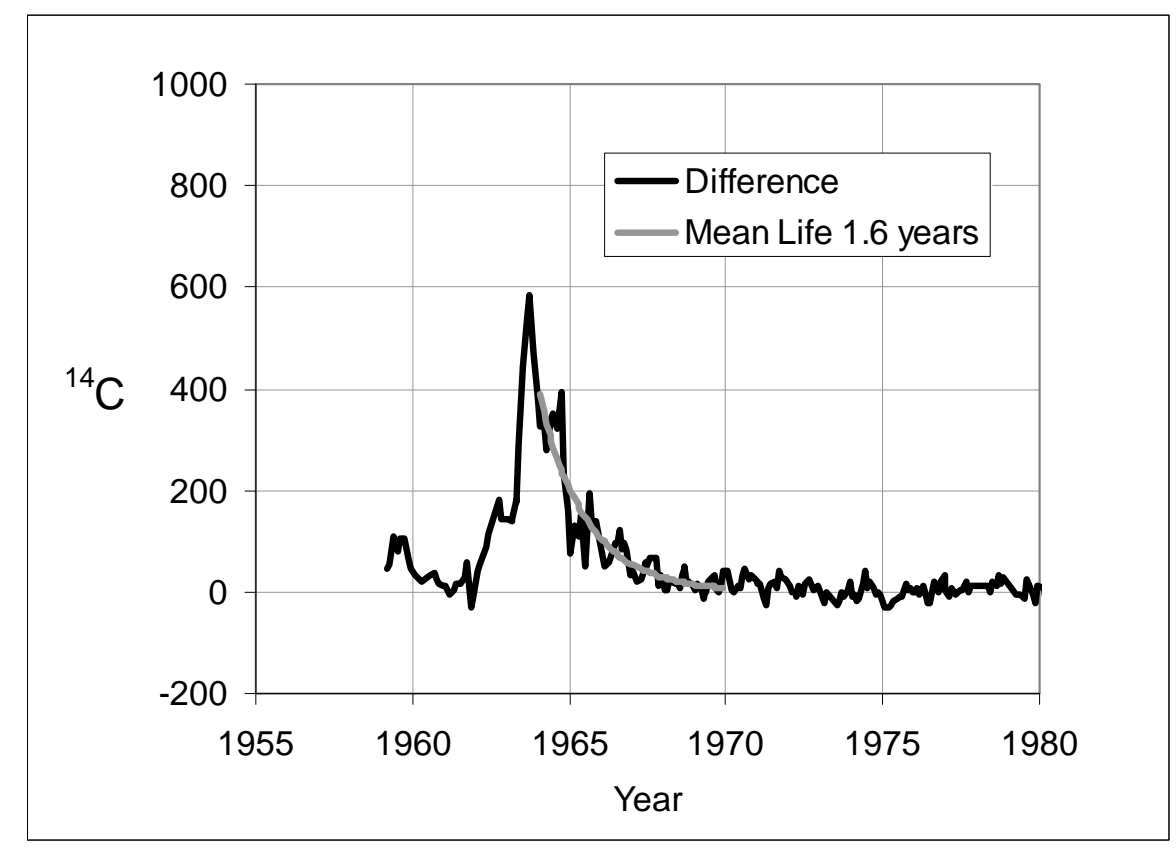

Figure 17 Timing differences of Northern and Southern Hemisphere carbon pulse. A number of massive weapons were detonated in the Arctic circle just before the Partial Test Ban Treaty came into force in October 1963. The measurements were made in New Zealand ${ }^{20}$ and Germany ${ }^{21}$.

If $75 \%$ of $\mathrm{CO}_{2}$ from fossil fuel is emitted north of latitude 30 then some time lag might be expected due to the sharp year-to-year variations in the estimated amounts left in the atmosphere. A simple model, following the example of the ${ }^{14} \mathrm{C}$ data with a one year mixing time, would suggest a delay of 
6 months for $\mathrm{CO}_{2}$ changes in concentration in the Northern Hemisphere to appear in the Southern Hemisphere.

A correlation plot of SIO year on year differences of monthly measurements at Mauna Loa against those at the South Pole is shown in Figure 18. The time difference is positive when the South Pole data leads the Mauna Loa data. Any negative bias (asymmetry in the plot) would indicate a delayed arrival of $\mathrm{CO}_{2}$ in the Southern Hemisphere.

There does not appear to be any time difference between the hemispheres. This suggests that the annual increases may be coming from a global or equatorial source.

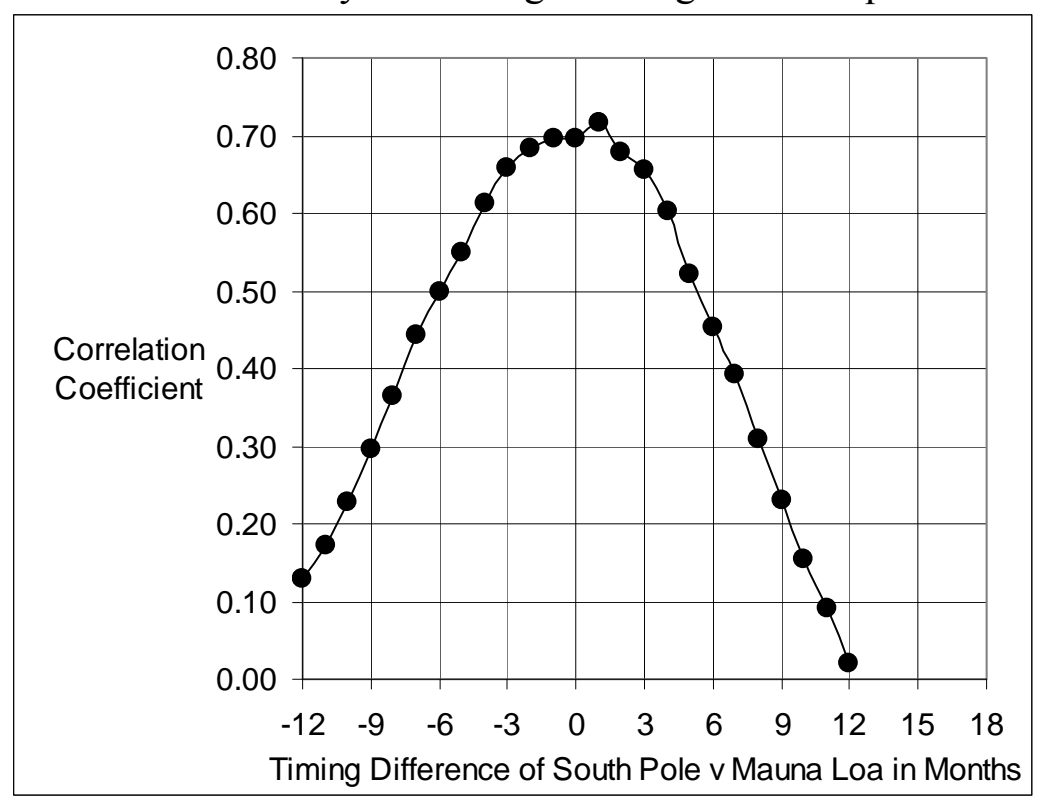

Figure 18 Variation in the correlation coefficient between year on year differences in measured monthly CO2 concentrations at Mauna Loa and the South Pole as the times series are separated. A negative timing bias would indicate the delayed arrival of $\mathrm{CO}_{2}$ in the Southern Hemisphere.

A similar comparison has been made for the variations of $\delta^{13} \mathrm{C}$ shown in Figure 19. The data has been analysed as 3-month averages. The result is not straightforward and suggests possible variations in the two hemispheres with time delays in both directions.

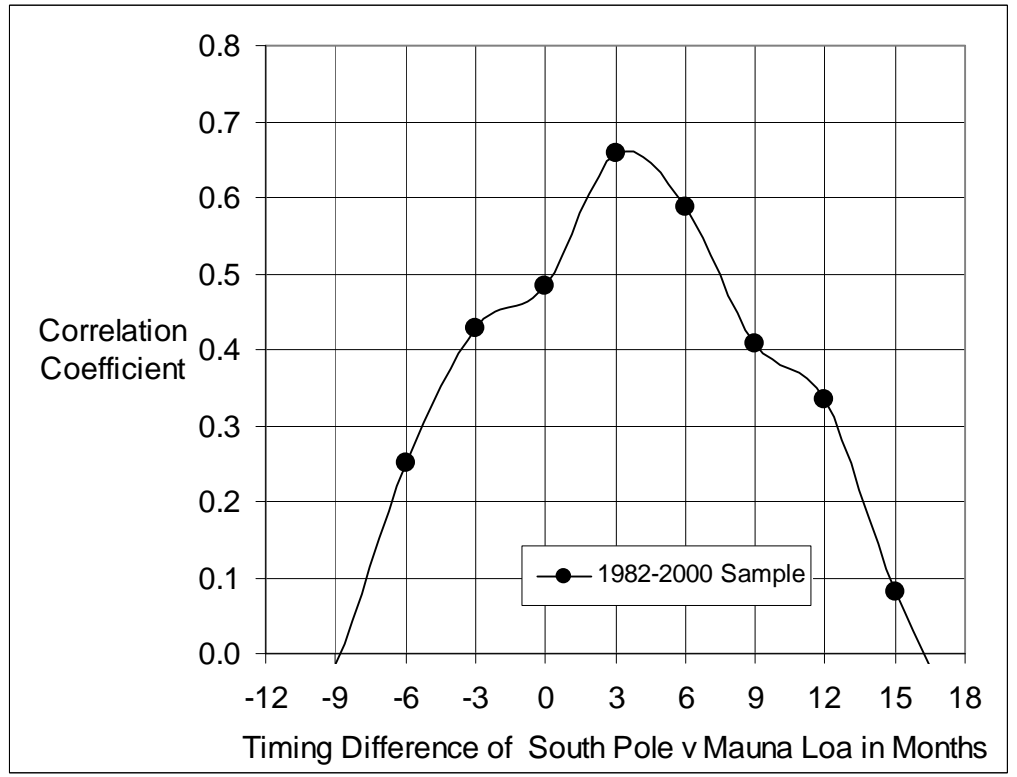

Figure 19 Variation in the correlation coefficient between year on year differences of three monthly average $\delta^{13} \mathrm{C}$ measurements at Mauna Loa and the South Pole as the times series are separated. A positive timing bias indicates the delayed arrival of $\mathrm{CO}_{2}$ in the Northern Hemisphere. 
If the increases in atmospheric $\mathrm{CO} 2$ are being driven by fossil fuel emissions then changes in the isotope ratio would be expected to occur first in the Northern Hemisphere and then move to the Southern Hemisphere. The result suggests that the changes in the isotope ratio start in the Southern Hemisphere. This suggests an equatorial or Southern source of $\mathrm{CO}_{2}$ emission.

\section{CONCLUSION}

During the 1977 to 2001 time period analysed:

Changes in the isotope ratio are discontinuous. The temporal peaks in ${ }^{13} \mathrm{C}$ appear to correlate with the $\mathrm{CO}_{2}$ concentration changes. Further the temporal peaks in ${ }^{13} \mathrm{C}$ and the $\mathrm{CO}_{2}$ peaks correlate with ENSO events.

The yearly increases of atmospheric $\mathrm{CO}_{2}$ concentrations have been nearly two orders of magnitude greater than the change to seasonal variation which implies that the fossil fuel derived $\mathrm{CO}_{2}$ is almost totally absorbed locally in the year that it is emitted.

A time comparison of the SIO measurements of $\mathrm{CO}_{2}$ at Mauna Loa with the South Pole shows a lack of time delay for $\mathrm{CO} 2$ variations between the hemispheres that suggests a global or equatorial source of increasing $\mathrm{CO}_{2}$. The time comparison of ${ }^{13} \mathrm{C}$ measurements suggest the Southern Hemisphere is the source. This does not favour the fossil fuel emissions of the Northern Hemisphere being responsible for ther observed increases.

All three approaches suggest that the increase of $\mathrm{CO}_{2}$ in the atmosphere may not be from the $\mathrm{CO}_{2}$ derived from fossil fuels. The ${ }^{13} \mathrm{C}$ data is the most striking result and the other two approaches simply support the conclusion of the first approach.

It is not obvious that the pulsed contributions of $\mathrm{CO} 2$ are related to continuous fossil fuel emissions given the seasonal data and the lack of a time delay in the Southern Hemisphere. Could it be a biogenic signal? After all the Northern Hemisphere has seasonal fluctuations of up to $15 \mathrm{ppm}$ so could a 2 ppm pulse be related to changing conditions in tropical lands as a result of El Nino's?

The conclusion is that $\mathrm{CO}_{2}$ emissions from fossil fuels do not make it to the "well mixed" atmosphere but are probably fixed locally. The increase in $\mathrm{CO}_{2}$ is driven by other processes related to the natural variability of the climate. Some of this $\mathrm{CO}_{2}$ variability is correlated with and may be related to ENSO events.

\section{$\underline{\text { Acknowledgements }}$}

The author wishes to thank W. Kininmonth, R. Carter and G. Paltridge for many extensive tutorials. In addition T. Segalstad and J. McLean have supplied valuable references and help on particular sections of the paper. 
Attachment: Table of Data used in Figures 13 to 15

\begin{tabular}{|c|c|c|c|c|c|c|c|c|}
\hline \multirow[t]{2}{*}{ Location and Latitude } & & \multirow[t]{2}{*}{$\begin{array}{l}\text { No. of } \\
\text { Years }\end{array}$} & \multicolumn{2}{|c|}{$\begin{array}{c}\text { Annual Increase } \\
\text { of } \mathrm{CO}_{2} \\
\text { ppm per year }\end{array}$} & \multicolumn{2}{|c|}{$\begin{array}{c}\text { Seasonal } \\
\text { Variations } \\
\text { of } \mathrm{CO}_{2} \\
\text { ppm }\end{array}$} & \multicolumn{2}{|c|}{$\begin{array}{l}\text { Annual Change of } \\
\text { Seasonal } \\
\text { Variations ppm per } \\
\text { year }\end{array}$} \\
\hline & & & Value & Error & Value & Error & Value & Error \\
\hline South Pole & -90 & 22 & 1.551 & 0.031 & 1.32 & 0.05 & 0.005 & 0.031 \\
\hline Macquarie Island & -54 & 9 & 1.676 & 0.093 & 1.52 & 0.09 & -0.006 & 0.093 \\
\hline Baring Head & -41 & 27 & 1.524 & 0.031 & 1.46 & 0.12 & 0.015 & 0.031 \\
\hline Cape Grim & -40 & 9 & 1.731 & 0.075 & 1.23 & 0.08 & 0.003 & 0.075 \\
\hline Kermadec & -29 & 22 & 1.571 & 0.040 & 0.97 & 0.26 & -0.005 & 0.040 \\
\hline Cape Ferguson & -19 & 10 & 1.696 & 0.124 & 2.49 & 0.22 & 0.089 & 0.124 \\
\hline American Samoa & -14 & 22 & 1.557 & 0.034 & 1.96 & 0.10 & 0.020 & 0.034 \\
\hline Christmas Island & 2 & 9 & 1.788 & 0.140 & 3.38 & 0.23 & 0.128 & 0.140 \\
\hline Mauna Loa & 19 & 22 & 1.591 & 0.037 & 6.85 & 0.07 & -0.013 & 0.037 \\
\hline Schauinsland & 48 & 20 & 1.548 & 0.042 & 13.57 & 0.36 & -0.113 & 0.046 \\
\hline Point Estevan & 49 & 7 & 1.848 & 0.314 & 12.81 & 0.50 & -0.175 & 0.314 \\
\hline Shetland Islands & 60 & 9 & 1.783 & 0.106 & 14.45 & 0.23 & -0.035 & 0.106 \\
\hline Alert & 82 & 19 & 1.569 & 0.065 & 15.54 & 0.15 & 0.062 & 0.065 \\
\hline Mean Values & & & 1.572 & 0.013 & & & -0.001 & 0.013 \\
\hline
\end{tabular}

Table Results of straight line fits to quantities derived from monthly measurements of $\mathrm{CO} 2$ concentrations from $\mathrm{SIO}^{2}$ and $\mathrm{CSIRO}^{8}$ data sources. 


\section{References}

${ }^{1}$ See for instance IPCC Climate Change 2007, Synthesis Report, Summary for Policymakers

${ }^{2}$ Keeling, C.D. and T.P. Whorf. 2005. Atmospheric $\mathrm{CO}_{2}$ records from sites in the SIO air sampling network. In Trends: A Compendium of Data on Global Change. Carbon Dioxide Information Analysis Center, Oak Ridge National Laboratory, U.S. Department of Energy, Oak Ridge, Tenn., U.S.A.

${ }^{3}$ Marland, G., T.A. Boden, and R. J. Andres. 2007. Global, Regional, and National $\mathrm{CO}_{2}$ Emissions. In Trends: A Compendium of Data on Global Change. Carbon Dioxide Information Analysis Center, Oak Ridge National Laboratory, U.S. Department of Energy, Oak Ridge, Tenn., U.S.A. ${ }^{4}$ Kenneth E. Peters, Clifford C. Walters, J. Michael Moldowan 2005. The Biomarker Guide, Cambridge University Press, page 137

${ }^{5}$ Hoefs, J. (1980): Stable isotope geochemistry, 2nd ed. Minerals and Rocks, 9. Springer-Verlag, $208 \mathrm{pp}$

${ }^{6}$ Blasing, T.J., C.T. Broniak, and G. Marland, 2004. Estimates of monthly carbon dioxide emissions and associated $\delta^{13} \mathrm{C}$ values from fossil-fuel consumption in the U.S.A. In Trends: A Compendium of Data on Global Change, Carbon Dioxide Information Analysis Center, Oak Ridge National Laboratory, U.S. Department of Energy, Oak Ridge, TN, U.S.A.

${ }^{7}$ Ohmoto, H. (1986): Stable isotope geochemistry of ore deposits. Reviews in Mineralogy 16,491559 and a recent measurement example:-Feely R. A., C. L. Sabine, F. J. Millero, A. G. Dickson, R. A. Fine, C. A. Carlson, J. Toole,T. M. Joyce, W. M. Smethie, A. P. McNichol, and R. M. Key. 2008. Carbon Dioxide, Hydrographic, and Chemical Data Obtained During the R/V Knorr Repeat Hydrography Cruise in the Atlantic Ocean: CLIVAR $\mathrm{CO}_{2}$ Sections A20_2003 (22 September-20 October 2003) and A22_2003 (23 October-13 November, 2003). Ed. A. Kozyr. ORNL/CDIAC154, NDP-089. Carbon Dioxide Information Analysis Center, Oak Ridge National Laboratory, U.S. Department of Energy, Oak Ridge, Tennessee.

${ }^{8}$ Segalstad, T.V. (1992): The amount of non-fossil-fuel $\mathrm{CO}_{2}$ in the atmosphere. American Geophysical Union, Chapman Conference on Climate, Volcanism, and Global Change, March 2327, 1992, Hilo, Hawaii. Abstracts, 25.

${ }_{9} 3^{\text {rd }}$ IPCC Report http://www.grida.no/climate/ipcc tar/wg1/097.htm\#fig31

${ }^{10}$ Keeling, C.D. and T.P. Whorf. 2004. Atmospheric $\mathrm{CO}_{2}$ concentrations derived from flask air samples at sites in the SIO network. In Trends: A Compendium of Data on Global Change. Carbon Dioxide Information Analysis Center, Oak Ridge National Laboratory, U.S. Department of Energy, Oak Ridge, Tennessee, U.S.A.

${ }^{11}$ Steele, L. P., P. B. Krummel and R. L. Langenfelds. 2007. Atmospheric $\mathrm{CO}_{2}$ concentrations from sites in the CSIRO Atmospheric Research GASLAB air sampling network (August 2007 version).

In Trends: A Compendium of Data on Global Change, Carbon Dioxide Information Analysis Center, Oak Ridge National Laboratory, U.S. Department of Energy, Oak Ridge, TN, U.S.A.

${ }^{12}$ Allison, C.E., R.J. Francey and P.B. Krummel. $\delta^{13} \mathrm{C}$ in $\mathrm{CO}_{2}$ from sites in the CSIRO Atmospheric Research GASLAB air sampling network, (April 2003 version). In Trends: A Compendium of Data on Global Change, Carbon Dioxide Information Analysis Center, Oak Ridge National Laboratory, U.S. Department of Energy, Oak Ridge, TN, U.S.A.

${ }^{13}$ Beck, E.G., 2008. 50 Years of Continuous Measurement of $\mathrm{CO}_{2}$ on Mauna Loa, Energy \& Environment 19, 7.pp. 1017-1028.

${ }^{14}$ Keeling, C.D, A.F. Bollenbacher, and T.P. Whorf. 2005. Monthly atmospheric ${ }^{13} \mathrm{C} /{ }^{12} \mathrm{C}$ isotopic ratios for 10 SIO stations. In Trends: A Compendium of Data on Global Change. Carbon Dioxide Information Analysis Center, Oak Ridge National Laboratory, U.S. Department of Energy, Oak Ridge, Tenn., U.S.A.

${ }^{15}$ Segalstad, T.V., Private communication

${ }^{16} \mathrm{http}: / /$ www.cdc.noaa.gov/people/klaus.wolter/MEI/

${ }^{17}$ Uhse, K., M. Schmidt and I. Levin. 1998. Atmospheric $\mathrm{CO}_{2}$ records from sites in the UBA air sampling network. In Trends: A Compendium of Data on Global Change. Carbon Dioxide 
Information Analysis Center, Oak Ridge National Laboratory, U.S. Department of Energy, Oak Ridge, Tenn., U.S.A.

${ }^{18}$ http://cdiac.ornl.gov/ftp/ndp058/LAT.TAB

${ }^{19} 3^{\text {rd }}$ IPCC Report http://www.grida.no/climate/ipcc tar/wg1/097.htm\#fig31

${ }^{20}$ Manning, M.R., and W.H. Melhuish. 1994. Atmospheric $\delta^{14} \mathrm{C}$ record from Wellington. In Trends: A Compendium of Data on Global Change. Carbon Dioxide Information Analysis Center, Oak Ridge National Laboratory, U.S. Department of Energy, Oak Ridge, Tenn., U.S.A.

${ }^{21}$ Levin, I., B. Kromer, H. Schoch-Fischer, M. Bruns, M. Münnich, D. Berdau, J.C. Vogel, and K.O. Münnich, 1994. $\delta^{14} \mathrm{CO}_{2}$ record from Vermunt. In Trends: A Compendium of Data on Global Change. Carbon Dioxide Information Analysis Center, Oak Ridge National Laboratory, U.S. Department of Energy, Oak Ridge, Tenn., U.S.A. 